Images dans le monde ibérique et ibéricoaméricain

5 | 2012

Le visible et l'invisible dans le monde hispanique et hispano-américain

\title{
La dialéctica de lo visible e invisible en la utilización de las fotografíasde los desaparecidos argentinos
}

\section{Graciela Villanueva}

\section{OpenEdition}

\section{Journals}

\section{Edición electrónica}

URL: http://journals.openedition.org/agedor/898

DOI: $10.4000 /$ agedor.898

ISSN: 2104-3353

\section{Editor}

Laboratoire LISAA

\section{Referencia electrónica}

Graciela Villanueva, «La dialéctica de lo visible e invisible en la utilización de las fotografíasde los desaparecidos argentinos », L'Âge d'or [En línea], 5 | 2012, Publicado el 01 marzo 2012, consultado el 16 diciembre 2019. URL : http://journals.openedition.org/agedor/898 ; DOI : 10.4000/agedor.898 


\title{
LA DIALÉCTICA DE LO VISIBLE E INVISIBLE EN LA UTILIZACIÓN DE LAS FOTOGRAFÍAS DE LOS DESAPARECIDOS ARGENTINOS
}

\begin{abstract}
Résumé : Les pancartes brandies par les Mères de la Place de Mai dès les premières manifestations publiques de protestation contre la dictature, les dossiers juridiques pour retrouver les responsables des disparitions, les articles nécrologiques in memoriam publiés par le journal Página 12 de Buenos Aires, les sites web et blogs de défense des droits de l'homme, les expositions de photographie et certaines manifestations artistiques de la dernière décennie font réapparaître les disparus. La photographie les rapproche et tâche de montrer ce qui ne se laisse pas photographier: le creux, l'absence, le temps qui sépare les vivants des disparus et des morts. Ces photos font contrepoint aux silhouettes sans visage brandies lors des manifestations de défense des droits de l'homme à partir de 1983. Cet article propose une étude de l'utilisation juridique, sociale et artistique de la photographie des disparus, tout particulièrement dans l'oeuvre de Marcelo Brodsky, Julio Pantoja, Lucila Quieto, Gabriela Bettini, Helen Zout, Pedro Camilo Pérez del Cerro, Clara Rossón, Inés Ulanovsky, Gustavo Germano, Verónica Maggi, Martín Acosta, Claudia Fontes et Nicolás Guagnini.
\end{abstract}

Mots-clés : photographie - disparus - dictature militaire argentine - articles nécrologiques - droits de l'homme

Resumen: Las pancartas enarboladas por las Madres de la Plaza de Mayo desde las primeras manifestaciones de protesta contra la dictadura, los legajos jurídicos que intentan encontrar y castigar a los responsables de las desapariciones, los recordatorios publicados por el diario Página 12 de Buenos Aires, los sitios web y los blogs de defensa de los derechos humanos, las muestras fotográficas y algunas otras manifestaciones artísticas de la última década hacen que los desaparecidos reaparezcan. La fotografía los acerca e intenta mostrar lo que no se deja fotografiar: el hueco, la ausencia, el tiempo que separa a los vivos de los desaparecidos y los muertos. Estas fotos constituyen el contrapunto de las siluetas sin rostro presentes en las manifestaciones de derechos humanos a partir de 1983. Este artículo propone un estudio de la utilización jurídica, social y artística de la fotografía de los desaparecidos, especialmente en la obra de Marcelo Brodsky, Julio Pantoja, Lucila Quieto, Gabriela Bettini, Helen Zout, Pedro Camilo Pérez del Cerro, Clara Rossón, Inés Ulanovsky, Gustavo Germano, Verónica Maggi, Martín Acosta, claudia Fontes y Nicolás Guagnini.

Palabras clave: fotografía - desaparecidos - dictadura militar argentina - recordatorios in memoriam - derechos humanos. 


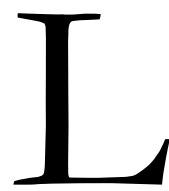

a última dictadura militar argentina sistematizó la desaparición, una práctica que le sirvió para deshacerse ilegalmente de toda persona que se opusiera o que se sospechara que se oponía al proyecto de país que los militares defendían. El número de detenidos-desaparecidos ${ }^{1}$ y de víctimas del terrorismo de estado ${ }^{2}$ es muy difícil de calcular con exactitud, ya que los registros fueron ocultados o destruidos antes de que los militares dejaran el poder. Las organizaciones de derechos humanos han logrado establecer una lista de unas catorce mil personas, que incluye a desaparecidos y muertos, pero como esta lista sólo incluye aquellas personas por las que se hizo una denuncia, sólo registra a una parte del número total, que se estima en alrededor de treinta mil personas. En efecto, en muchos casos no hubo denuncias y esto por múltiples causas: desvinculación de la víctima con su familia, inexistencia de parientes o amigos, miedo, desconocimiento de la manera de reclamar por la persona desaparecida, etc.

En « Arte, memoria y archivo », Leonor Arfuch escribe:

...la desaparición [es una] figura que sugiere y a la vez no nombra la muerte ni el lugar de los cuerpos sustraídos a los ritos del reconocimiento. Pero es precisamente esa figura trágica del vacío, la ausencia, el desconocimiento, la que ha agitado sin descanso la reivindicación de la memoria por su contrario: la presencia callejera de la demanda, las fotos y retratos, las siluetas y manos, la "aparición con vida », primera consigna contra el (im)posibilismo y el silencio que marcó al mismo tiempo la posibilidad de la justicia (ARFUCH, p. 35-36).

El objetivo de este trabajo es estudiar la paradoja de la presencia y la ausencia en la utilización de las fotos de los detenidos-desaparecidos de la última dictadura militar argentina y mostrar el juego dialéctico entre lo visible y lo invisible que estas fotos instauran en la obra de diversos artistas argentinos de la última década (fotógrafos y escultores).

\footnotetext{
${ }^{1}$ La Convención Interamericana sobre Desaparición Forzada de Persona firmada en 1994 define como desaparición forzada (delito de lesa humanidad imprescriptible) «a la privación de la libertad a una o más personas, cualquiera que fuere su forma, cometida por agentes del Estado o por personas o grupos de personas que actúen con la autorización, el apoyo o la aquiescencia del Estado, seguida de la falta de información o de la negativa a reconocer dicha privación de libertad o de informar sobre el paradero de la persona, con lo cual se impide el ejercicio de los recursos legales y de las garantías procesales pertinentes ». Se trata de una práctica reconocida y justificada por los militares argentinos del llamado "Proceso de Reorganización Nacional»(1976-1983). El 14 de diciembre de 1979 Jorge Videla declara al diario Clarín de Buenos Aires: "¿Qué es un desaparecido? En cuanto éste como tal, es una incógnita el desaparecido. Si reapareciera tendría un tratamiento $X$, y si la desaparición se convirtiera en certeza de su fallecimiento tendría un tratamiento Z. Pero mientras sea desaparecido no puede tener ningún tratamiento especial, es una incógnita, es un desaparecido, no tiene entidad, no está, ni muerto ni vivo, está desaparecido ». Y muchos años después, Videla declara: «No, no se podía fusilar. Pongamos un número, pongamos cinco mil. La sociedad argentina, cambiante, traicionera, no se hubiera bancado los fusilamientos: ayer dos en Buenos Aires, hoy seis en Córdoba, mañana cuatro en Rosario, y así hasta cinco mil, 10 mil, 30 mil. No había otra manera. Había que desaparecerlos. Es lo que enseñaban los manuales de la represión en Argelia, en Vietnam. Estuvimos todos de acuerdo. ¿Dar a conocer dónde están los restos? Pero ¿qué es lo que podíamos señalar? ¿El mar, el Río de la Plata, el Riachuelo? Se pensó, en su momento, dar a conocer las listas. Pero luego se planteó: si se dan por muertos, enseguida vienen las preguntas que no se pueden responder: quién mató, dónde, cómo ». Declaración de Videla el el 25 de agosto de 1998 en la entrevista concedida al periodista Guido Braslavsky Núñez, citada en SeOAne, María y Muleiro, Vicente, El dictador, Buenos Aires: Sudamericana, 2001, p. 215.

2 Se habla de «terrorismo de estado» cuando el estado permite a organizaciones terroristas militares y paramilitares amedrentar a la población civil con diversas formas de coacción, persecución, secuestro, privación de la libertad, tortura y asesinato.
} 


\section{El corpus}

En el corpus que sirve de base a este trabajo pueden distinguirse dos grandes usos de las fotografías de los desaparecidos:

- un uso «utilitario », judicial y político, que es el que se hace en manifestaciones y en publicaciones en internet, en televisión y en periódicos, así como en los juicios contra los represores y torturadores. Aunque el objetivo de estas fotos no haya sido nunca prioritariamente artístico, debemos tener en cuenta que en el movimiento de derechos humanos en Argentina participaron desde el comienzo fotógrafos y artistas plásticos;

- un uso «estético » o «artístico » (que no por ello deja de ser político) en ensayos o muestras de fotógrafos y artistas plásticos. Muchos de estos artistas (pero no todos) son familiares de detenidos-desaparecidos: es el caso de Marcelo Brodsky, Clara Rosson, Lucila Quieto, Gabriela Bettini, Verónica Maggi, Gustavo Germano, Nicolás Guagnini, pero no de Inés Ulanovsky, Julio Pantoja o Claudia Fontes (o al menos el parentesco no es algo que esté explícito en la presentación de sus muestras). En otros casos se trata de personas que corrieron serios riesgos de desaparecer, como le pasó a Helen Zout, quien de algún modo desapareció para no desaparecer, ya que tuvo que vivir encerrada durante más de dos años para escapar al terrorismo de estado. La dimensión autobiográfica de las obras resulta en todos ellos evidente.

El uso « utilitario » de las fotos de los desaparecidos:

Desde sus primeras manifestaciones en plena dictadura los familiares de los desaparecidos utilizaron las fotos como una prueba de la existencia de aquellos por quienes reclamaban. Sus fotos vuelven en las manifestaciones que reclaman esclarecimiento y justicia, en internet, en televisión, en periódicos, en los juicios contra los represores y torturadores. La presencia de un ser humano en la foto se usa para denunciar su ausencia en la realidad.

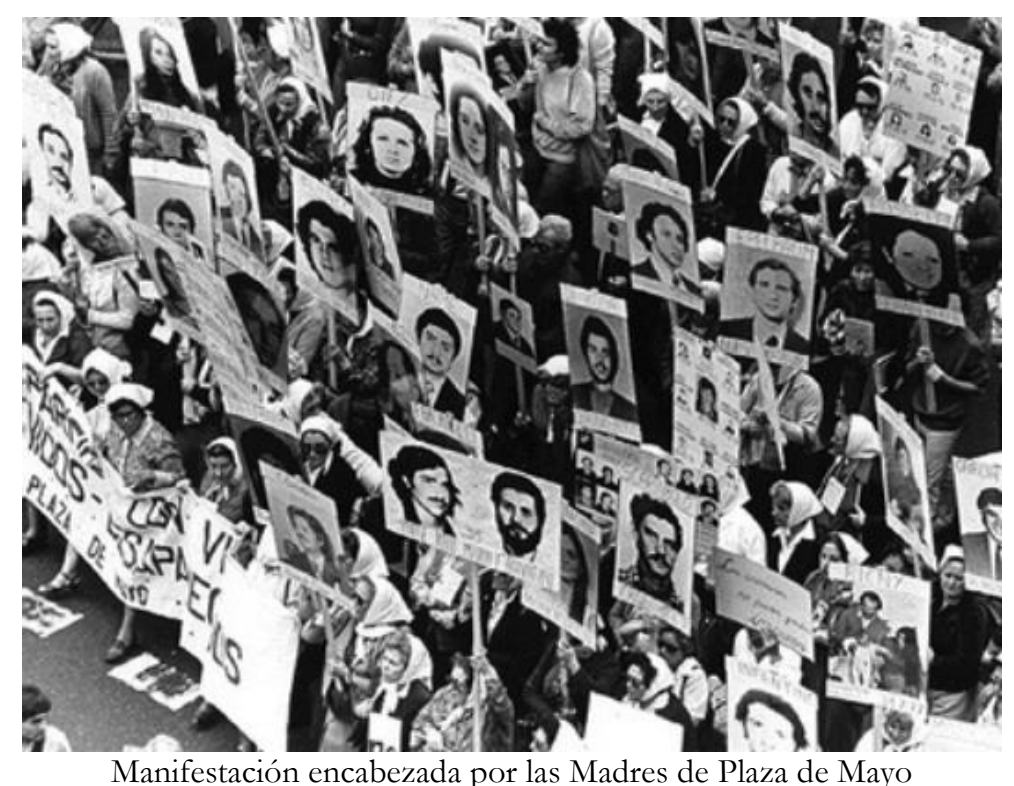


Estas fotos de individuos, con nombres, pueden leerse como el contrapunto de las siluetas anónimas que a partir de 1983 acompañaron las manifestaciones de los organismos de derechos humanos (ver BrUZZONE, Gustavo y LONGONI, Ana, 2008).

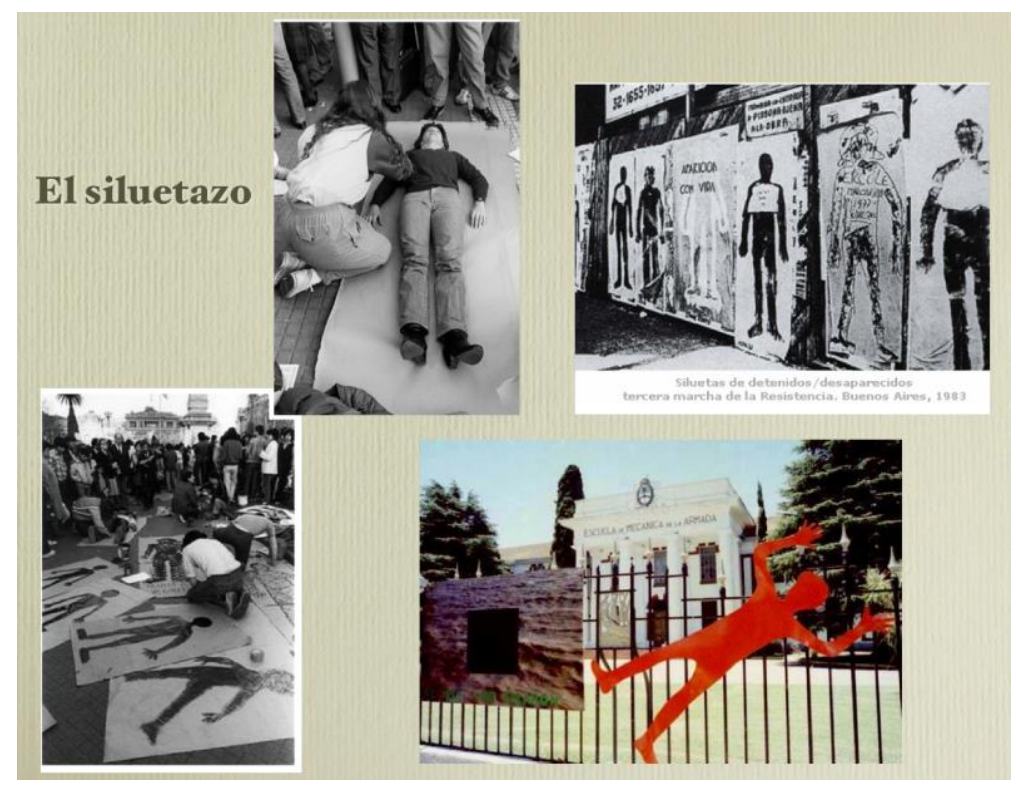

Dentro de este corpus, ocupan un lugar especial las fotos «sacadas » por Víctor Basterra de la Escuela de Mecánica de la Armada, que sirvieron como prueba en los juicios contra represores y que volvieron a aparecer en libros y en muestras fotográficas. Respecto de ellas se impone una aclaración: aunque Basterra es fotógrafo, él no sacó esas fotos, al menos no las de sus compañeros desaparecidos. Es decir, no apretó el botón de la cámara de fotos. Sin embargo, como escribe Marcelo Brodsky en «Sacar fotos » (BRODSKY, 2005, p.31), Basterra sí las sacó, y lo hizo dos veces, jugándose la vida, porque las extrajo primero de una pila destinada a la hoguera y al olvido y porque luego las sacó de la Escuela de Mecánica de la Armada, ocultas en su sexo .

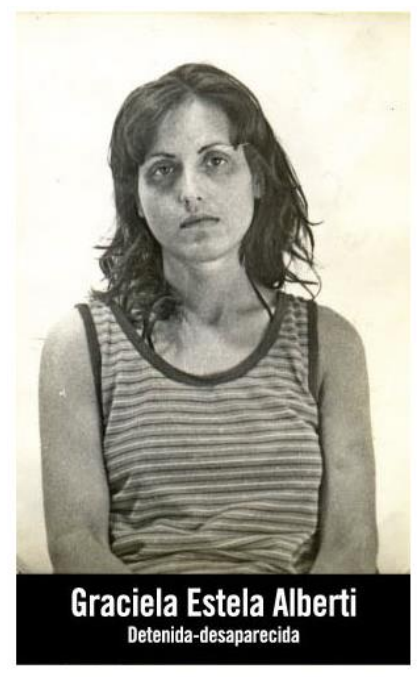

Foto de una desaparecida sacada de la ESMA por Basterra

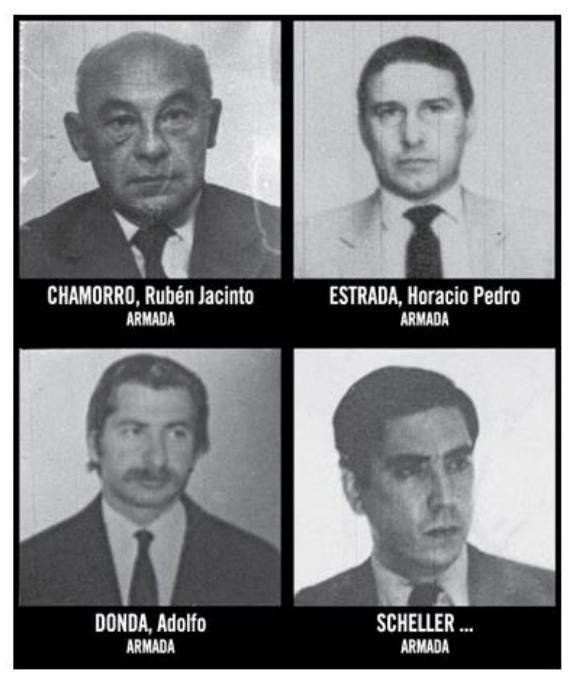

Fotos de represores sacadas de la ESMA por Basterra 
Sobre estas fotos, y sobre otras sacadas de diversos archivos militares o policiales en estos últimos años, es preciso observar que, en el momento de ser expuestas en un conjunto, como lo hizo Víctor Basterra al publicarlas en el libro compilado por Marcelo Brodsky de 2005 o, un año más tarde, en la muestra Rostros (2006), las fotos toman otro sentido $^{3}$. Las imágenes (fijadas cuando el detenido llegaba a la ESMA, en general antes de la tortura) fueron concebidas como parte de un dispositivo de control de los represores. En el nuevo contexto, las imágenes de los desaparecidos se convierten en argumentos de denuncia, en pruebas jurídicas que acusan a los responsables de las desapariciones y en expresión y testimonio contundente del horror, ya que condensan el desamparo y el dolor de quienes sentían la proximidad de la peor muerte.

Es necesario agregar que las fotos de Basterra y las que durante la democracia se han encontrado en archivos militares antes secretos no son la únicas sustraídas a la barbarie y al olvido. En la voluntad de borrar completamente a sus oponentes, en el momento de los secuestros, los represores también robaban sus fotos. Esto es algo que vuelve con frecuencia en los testimonios de los familiares ${ }^{4}$, algo que nos permite pensar que todas las fotos de los desaparecidos le fueron de algún modo «sacadas » al terrorismo de estado.

Recordemos además que en la contracara de estas fotos están las otras, las de los verdugos, en los periódicos, en los juicios, en la televisión y en los « escraches », exhibidas como prueba y como aguijón contra el olvido (alguna de ellas sacadas también en/de la ESMA por Basterra). Aclaremos que los «escraches» son manifestaciones públicas frente al domicilio o lugar de trabajo de alguien a quien se quiere denunciar. La asociación H.I.J.O.S. (Hijos por la Identidad y la Justicia contra el Olvido y el Silencio) comenzó a organizar este tipo de acciones a partir de 1995 para denunciar a los represores que con el gobierno de Carlos Menem habían recuperado su libertad o los que nunca habían sido juzgados a pesar de los testimonios y denuncias en contra de ellos. Las modalidades de acción fueron muy diversas: pintadas, exhibición de la foto del torturador, teatro callejero, volantes, carteles, insultos, lanzamiento de huevos o de pintura roja contra el domicilio, etc.

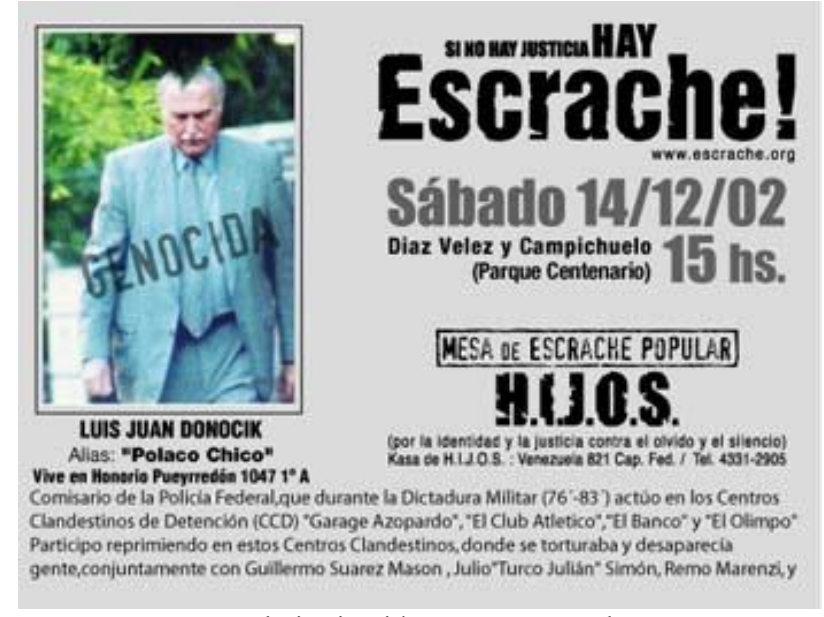

Foto de invitación a un « escrache»

\footnotetext{
${ }^{3}$ Escribe Jordana Blejmar en 2008: « No es sólo la imagen como montaje sino las imágenes montadas en serie y leídas en diálogo paradigmático con otras, lo que permite construir nuevas narrativas sobre el pasado. El carácter serial de los trabajos, que imitan la estructura fragmentaria y episódica del álbum, cuyos espacios entre imágenes remiten a lagunas de la memoria, invita al armado de una cronología que no corresponde a la real ».

4 Valeria Durán analiza en 2006 el ensayo fotográfico Fotos tuyas de Inés Ulanovsky y observa que, en la mayoría de los testimonios, se consigna el hecho de que hubo fotos robadas.
} 
La estrategia de presencia y ausencia del desaparecido en el trabajo de justicia y de memoria no sólo se desprende de la recurrencia de las imágenes (y en particular de las fotos), sino también, con igual fuerza también, de la repetición de los nombres, que en general se inscriben junto a las fotos y que en los diversos espacios de conmemoración vuelven a ocupar un lugar importante. Así lo muestra el Monumento a las víctimas del terrorismo de estado en el Parque de la Memoria de Buenos Aires, que tiene la forma de un muro con espacio para treinta mil nombres y en el que pueden leerse los de todos los muertos y desaparecidos registrados hasta la fecha.

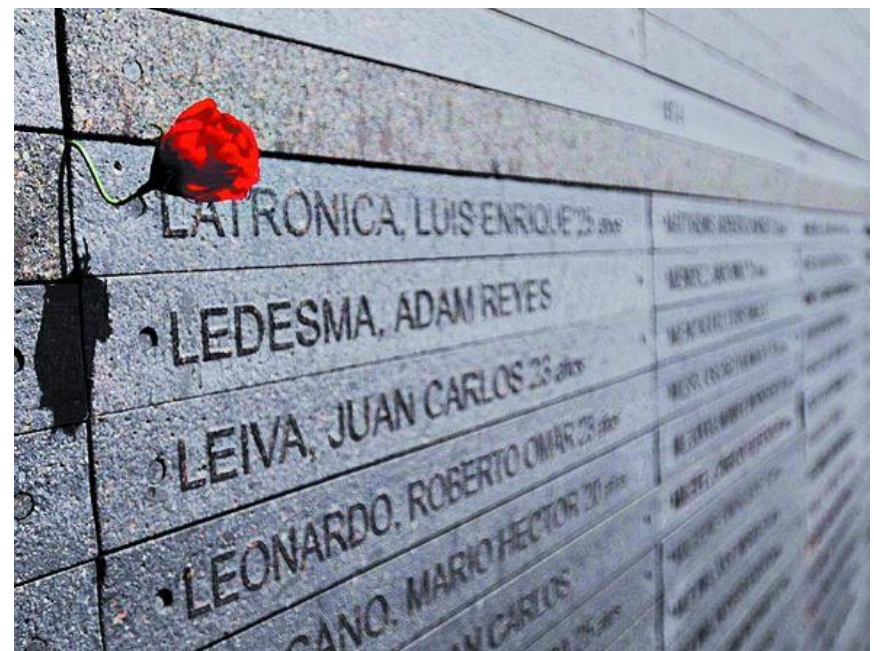

Nombres de los muertos y desaparecidos en el muro del Parque de la Memoria

En el catálogo de presentación del Parque de la Memoria $^{5}$ y en las declaraciones de los familiares de los desaparecidos se subraya la importancia del nombre y de su inscripción en la piedra. En un artículo publicado en el momento de la inauguración del Monumento a las Víctimas del terrorismo de estado, Marcelo Brodsky escribe:

Cada nombre está escrito en un ladrillo único de piedra de pórfido de la Patagonia. Las piedras se pueden tocar y se dispuso que estén a la altura a la que puede llegar el brazo extendido de una persona de mediana estatura. Cada nombre se integra en un conjunto, en una generación, en miles de personas reales que vivieron y que encuentran en el Monumento una unidad y un reconocimiento, un único nombre común, y la posibilidad de narrar desde su silencio la historia de todos. [...] Cada familia que tenga un desaparecido tendrá en el Parque de la Memoria un lugar donde recordar su nombre ${ }^{6}$.

Los testimonios de los familiares confirman que el nombre también se relaciona con este juego de presencia y ausencia. Otro artículo publicado en el periódico Página 12 en esa misma época lo demuestra desde sus primeras líneas:

\footnotetext{
${ }^{5}$ Ver ALEgre, Gabriela y AYERDI, Cecilia, 2010.

6 «Memoria, Verdad, Justicia » en Página 12, 8 de noviembre de 2007. En relación con el monumento del Parque de la Memoria es interesante observar que se inspira en el muro en memoria de los caídos en Vietnam que diseñó Maya Lin y que se inauguró en Washington en 1982, aunque hay que aclarar que en el monumento argentino no se percibe la ambigüedad que puede captarse en el monumento estadounidense. El muro de mármol negro que se hunde en la tierra mientras refleja la imagen de la capital de los Estados Unidos puede, en efecto, leerse como una crítica a una guerra decidida por un gobierno democrático que mandó morir a buena parte de una generación. Y así lo entendieron quienes exigieron que se hiciera otro monumento que celebrara más claramente el valor de los combatientes estadounidenses en Vietnam.
} 
Vengo a tocar el nombre de mi hijo", dijo Tati Almeyda, de la línea fundadora de Madres de Plaza de Mayo, al acercarse a la placa grabada con el nombre de su hijo desaparecido. («Visita al Parque de la Memoria », Página 12, 30 de agosto de 2007)

El muro del Parque de la Memoria es monumento y es lápida para los que no tienen lápida. En este sentido se acerca a lo que Luis Gusmán analiza muy bien en el postfacio de su libro Epitafios. El derecho a la muerte escrita (2005) dedicado a los recordatorios publicados en el diario Página 12 de Buenos Aires. Gusmán observa que ante la falta de cuerpos, tumbas y epitafios de las víctimas del terrorismo de estado en Argentina, el ritual que, desde hace más de veinte años, inexorablemente retorna en el diario Página 12 en cada aniversario de una desaparición, es una forma de reconstruir «esa vía simbólica exterminada, esa epigrafía borrada en cuerpo y letra ${ }^{7}$.

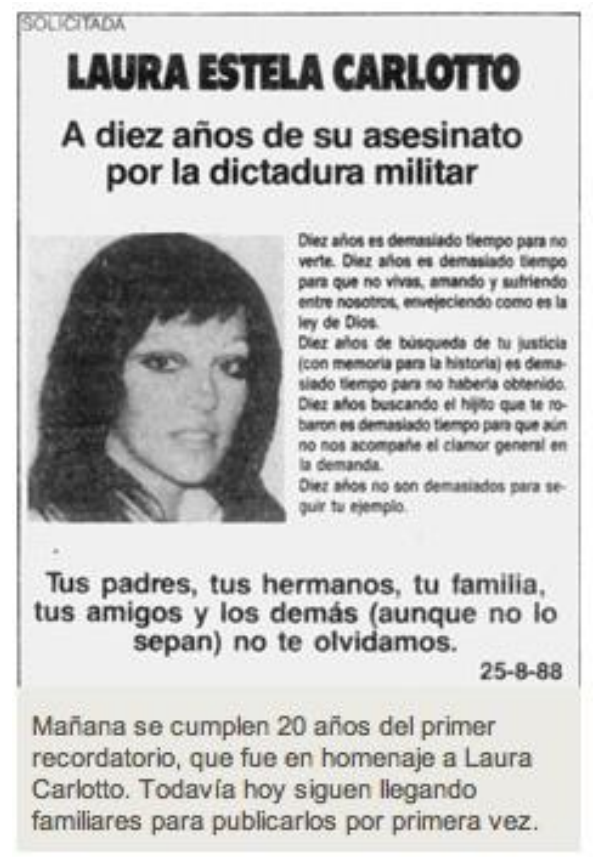

Recordatorio publicado en Página 12

Otro uso de las fotografías es el que han hecho periodistas, familiares y militantes de los derechos humanos en un intento de demostrar, a partir de un parecido, la identidad de hijos adoptados, hijos que, según estos periodistas, familiares y militantes de derechos humanos, fueron robados por los represores y a quienes les fue sustraída su verdadera identidad. El caso que más repercusión periodística tuvo es el de Marcela Noble, hija

\footnotetext{
7 GuSMÁN, Luis, « Cicatrices », in: Suplemento Radar de Página 12, 12 de junio de 2005. En el postfacio de su libro Epitafios. El derecho a la muerte escrita (2005), Gusmán analiza por un lado «la política de los huesos » de los militares, cifrada en una consigna central: «no entregar los cadáveres», y por otro lado el « cinismo militar» que culpó a los guerrilleros de la imposibilidad de identificarlos (Viola declaró que no podían identificase los cuerpos porque los guerrilleros utilizaban documentos falsos o circulaban sin documentación). Gusmán demuestra que esta línea prosigue hoy en la política de publicación de avisos fúnebres de los periódicos argentinos y para hacerlo cita un ejemplo muy elocuente : el 20 de agosto de 2004 el periódico conservador La Nación publica el aviso fúnebre de Armando Lambruschini, integrante de la junta militar que gobernó el país entre 1978 y 1981. Gusmán observa cómo ese aviso « lo rehabilitó post mortem al acompañar su nombre con el grado de 'Almirante' del que el Estado lo había privado. Una generosidad extrema, contrastante con la negativa del diario a admitir, meses atrás, que la palabra 'desparecida' figurara en una sencilla esquela de la misma sección ».
} 
adoptada en la época de la dictadura por Ernestina Noble, la directora del diario Clarín de Buenos Aires. En un momento la familia de una desaparecida intentó demostrar que Marcela era en realidad Matilde Lanuscou, una beba secuestrada en 1976, y en otro momento María Isabel Mariani, una de las fundadoras de Abuelas de Plaza de Mayo, emitió la hipótesis de que Marcela pudiera ser su nieta Clara Anahí, también secuestrada durante la dictadura. Más allá de la verosimilitud y del resultado concreto de las investigaciones judiciales (muy complicadas en este caso, ya que Marcela Noble se negó durante muchos años a someterse a las pruebas genéticas), es interesante hacer referencia a este uso particular de las fotos de los desaparecidos ${ }^{8}$.

\section{El uso « artístico » de las fotografías de los desaparecidos}

Además del uso de las fotografías de los desaparecidos en las manifestaciones de protesta y en los juicios contra los represores y torturadores, es interesante estudiar el uso « estético » o « artístico » (que no por ello deja de ser político) que los fotógrafos y artistas plásticos hacen de las fotografías?. Nos limitaremos a presentar un ejemplo de cada una de las muestras fotográficas de los artistas que nos interesan y destacar algunos de los procedimientos utilizados por cada fotógrafo. Las muestras pueden verse, en una versión más completa, en los sitios web citados en la bibliografía.

\section{Marcelo Brodsky, Buena memoria (1997) y Nexo (2001):}

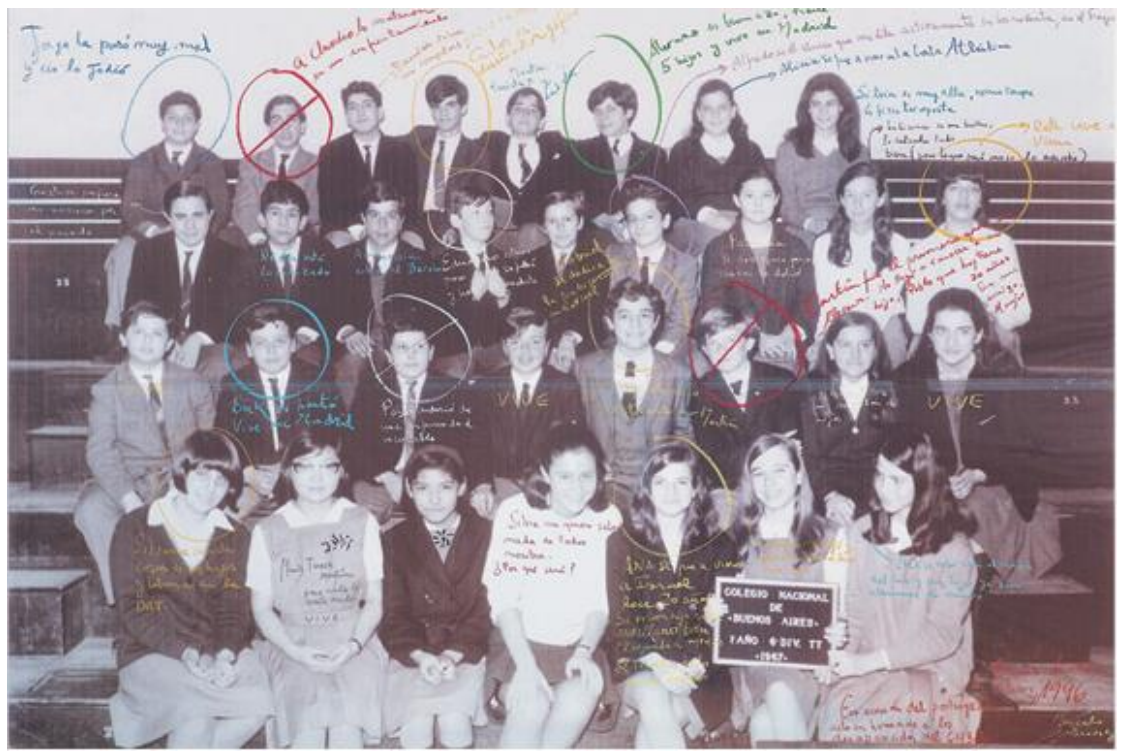

\footnotetext{
${ }^{8}$ Sobre la identidad de Marcela Noble pueden consultarse los artículos y fotos publicados en los sitios web citados en la bibliografía.

9 Muchos de estos ensayos fotográficos han sido objeto de estudio en los últimos años, como bien lo demuestran los estudios, citados en la bibliografía, de Leonor Arfuch, Florencia Battiti, Jordana Blejmar, Gustavo Bruzzone, Ana Longoni, Valeria Durán, Silvia Kuschnir, Claudia Feld, Natalia Fortuny, Gabriel Gatti, Nelly Richard, Sebastián Russo y Marisa Strelezenia, publicados entre 2000 y 2011.
} 
Se observa aquí un juego de intervención sobre la foto (la escritura de hoy en la foto de ayer).

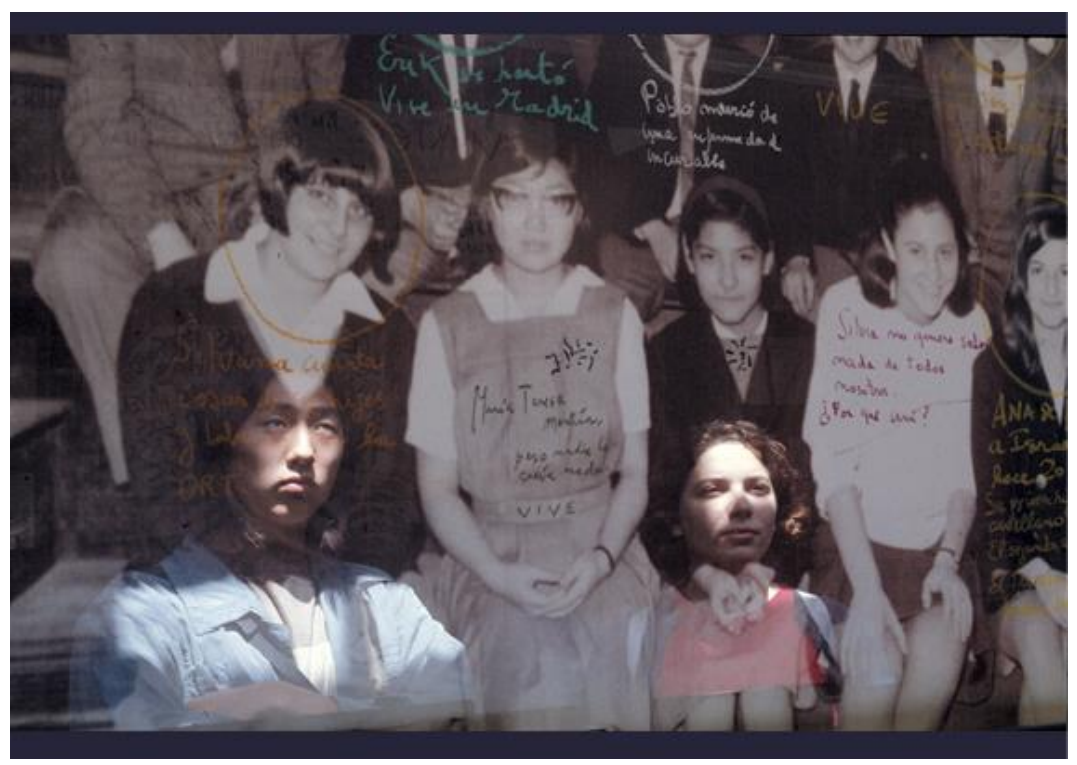

Aquí se crea un juego de reflejos entre los alumnos del Colegio Nacional de Buenos Aires que eran jóvenes en los años 70 y los alumnos de hoy. La nueva foto hace posible el encuentro entre dos generaciones.

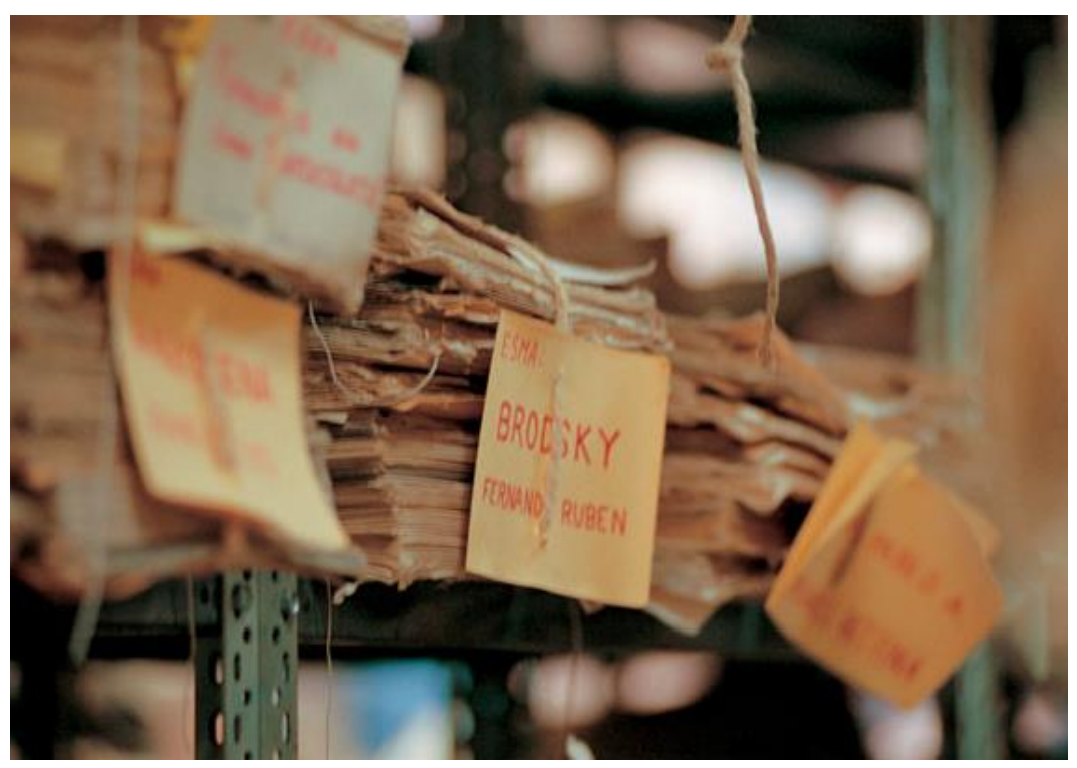

En esta foto se constata la importancia del nombre, en este caso el nombre en el legajo de un desaparecido (en este caso Fernando Brodsky, hermano del fotógrafo); en otras fotos de Marcelo Brodsky, aparece el nombre de los campos de detención y tortura. 
Julio Pantoja, Los hijos, Tucumán veinte años después (1996-2001):

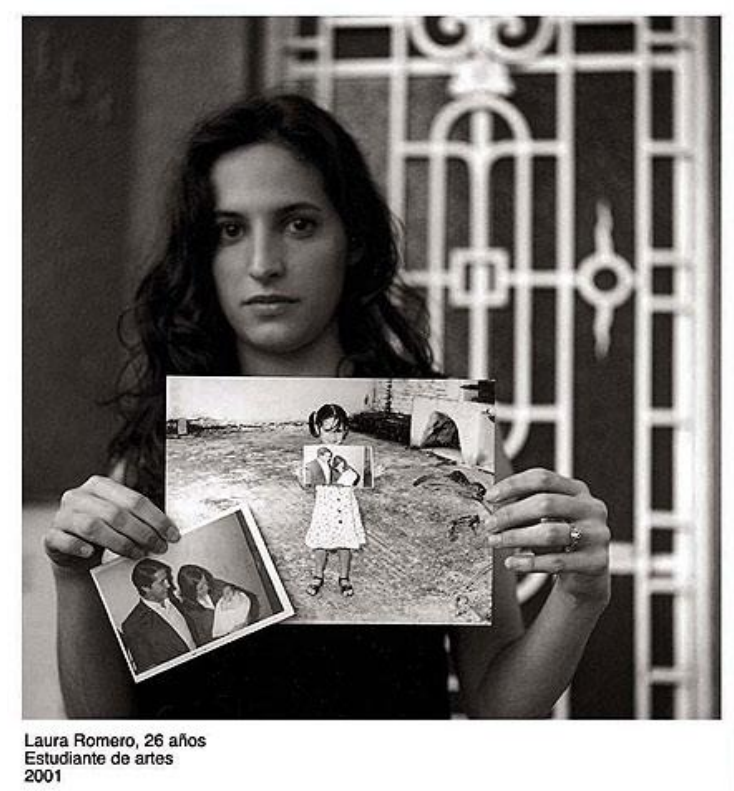

Las fotos de Pantoja narran el encuentro entre dos generaciones, ya que incluyen la foto de la persona desparecida en manos de su hijo/a. Pantoja no dio ninguna consigna a los jóvenes, simplemente les dijo que quería retratarlos y que ellos podían elegir cómo. Fueron los hijos quienes, en su gran mayoría, eligieron retratarse con las fotografías de sus padres.

Lucila Quieto, Arqueología de la ausencia (1999-2001)

/ Gabriela Bettini, Recuerdos inventados (2003):

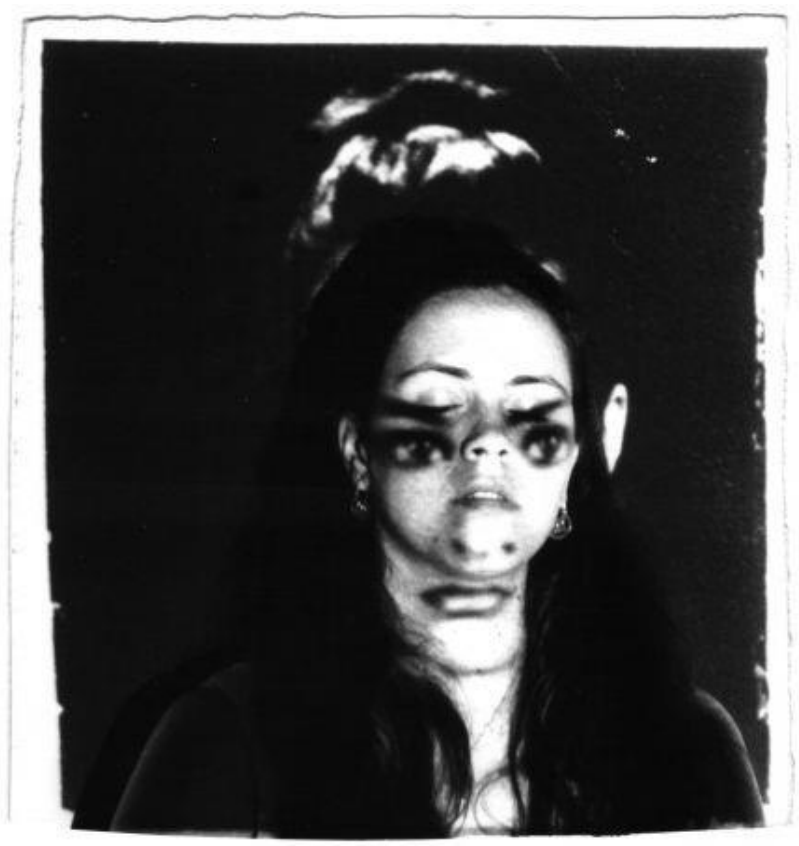

Lucila Quieto 
LUCILA. En los ojos de mi padre veo el océano. Trabajaba en el puerto de Buenos Aires. Hacía política en el barrio de Mataderos. Era un montonero. Fue secuestrado el 20 de agosto de 1976. Se llamaba Carlos Alberto Quieto. Yo me llamo Lucila. Tengo 24 años. Soy fotógrafa. En mis obras uno el pasado con el presente para no olvidar. El presente con el futuro para exigir justicia.

Lucila Quieto le pidió a cada hijo que buscara en sus cajas una foto de su padre. La fotógrafa reprodujo la foto elegida en forma de diapositiva. En un segundo encuentro con el hijo del desaparecido proyectó la diapositiva sobre una pared, pidió al hijo que se introdujera entre la cámara y la imagen y registró el resultado de la experiencia en una o varias fotos. De esta manera Quieto construye un encuentro. La nueva foto integra las fotos de ayer de una manera menos convencional que la de un hijo que sostiene una foto. Y cuando la proyección de la diapositiva se hace sobre el cuerpo del hijo, se suelen producir confusiones o fusiones entre el presente y del pasado (esto se ve en el trabajo de Quieto y también en el de Maggi, que presentamos más adelante).

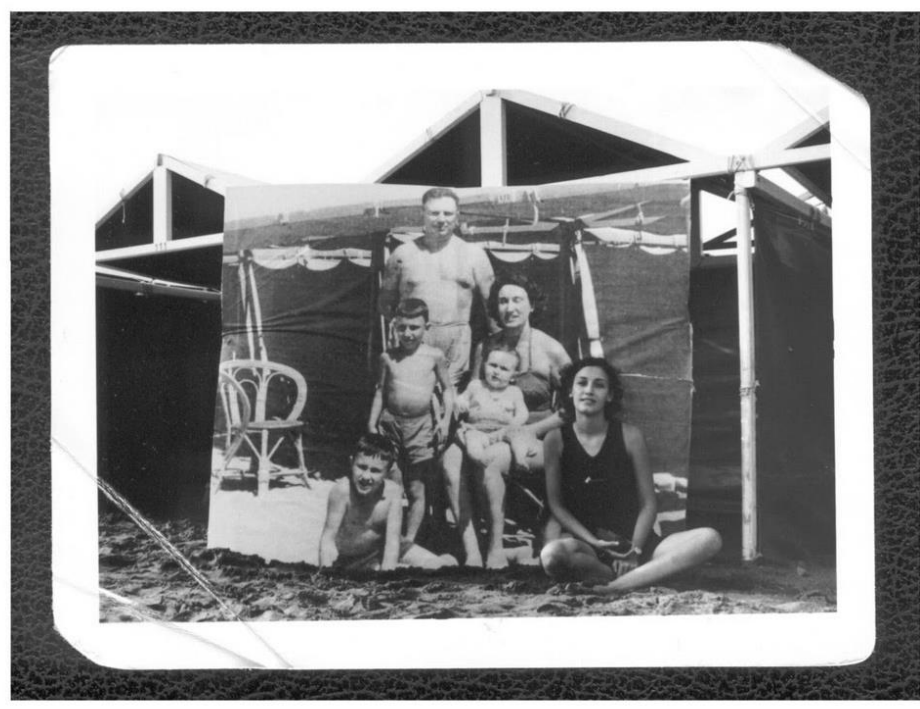

Foto de familia en Mar del Plata

Gabriela Bettini

Gabriela Bettini inventa, en cambio, recuerdos con su tío Marcelo y con su abuelo Antonio. En estos recuerdos inventados predomina el humor. Según Ana Amado, a quien cita Jordana Blejmar, en Quieto y en Bettini:

la opción de un armado artesanal en lugar de aquel que habilita la tecnologia digital [...] resulta de la búsqueda de un efecto deliberado en el espectador: nada debe hacernos creer que el encuentro entre generaciones es real.

Retomando las palabras usadas por Bettini cuando trabajó como curadora de la muestra de Quieto, Blejmar subraya cómo « los hijos ponen el cuerpo en lugar de los padres, haciendo acto de una literalidad siniestra » (BLEJMAR, p. 209) 
Helen Zout, Huellas de desapariciones (2003):

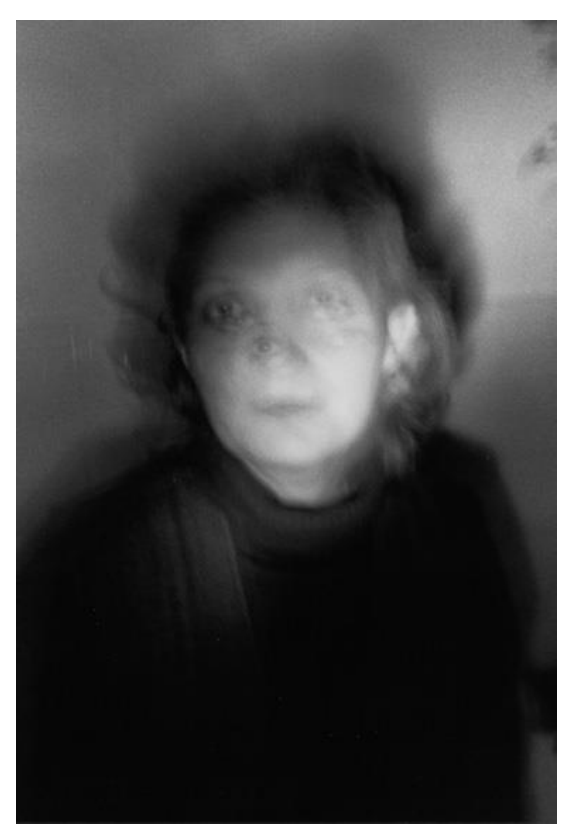

Entre las fotos de Helen Zout las hay de muertos (cráneo perforado por una bala, foto de un militante muerto sacada del archivo policial) y de sobrevivientes. En estas últimas puede destacarse lo que Zout concibe como un trabajo con el tiempo: son fotos de exposición lenta, levemente movidas, lo cual constituye una forma de plasmar el paso doloroso del tiempo.

Pedro Camilo Pérez del Cerro, El viaje de papá (2005):

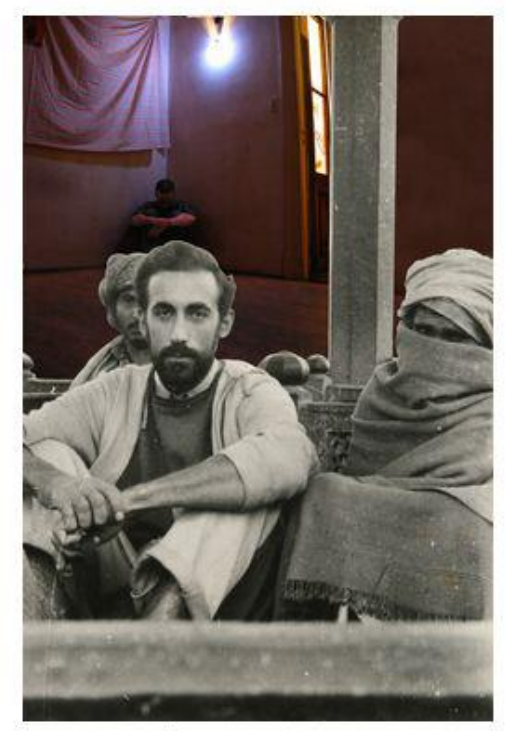

J Triania an hather de cunjustap,

Hernán Pérez del Cerro era fotógrafo y fue asesinado el 9 de junio de 1977 por la Dictadura Militar. El ensayo fotográfico de su hijo Pedro Camilo consta de una serie de 
montajes de las fotos del viaje de Hernán por diferentes países del mundo en la década del 60 con autorretratos de su hijo. Pedro Camilo utiliza un procedimiento similar a Quieto y Bettini, ya que produce un encuentro entre pasado y presente en la nueva foto. La particularidad de este corpus es que Hernán Pérez del Cerro era fotógrafo. El montaje suele jugar con la oposición entre el blanco y negro de la foto del pasado y el color de la foto de presente, marcando así, al mismo tiempo que el encuentro, la distancia insalvable.

\section{Clara Rossón, Tarde (o temprano) (2006):}

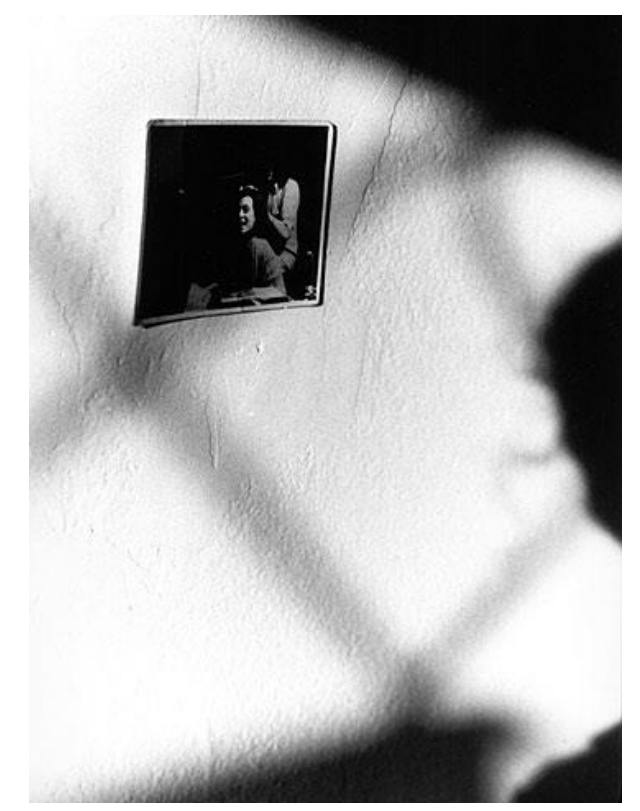

Clara Rosson insiste en el detalle, la mirada al sesgo que al fotografiar las viejas fotos les otorga nueva vida, y sobre todo en las sombras, porque las sombras expresan lo que siempre fueron y son esos desaparecidos para la artista.

Inés Ulanovsky, Fotos tuyas (2006):

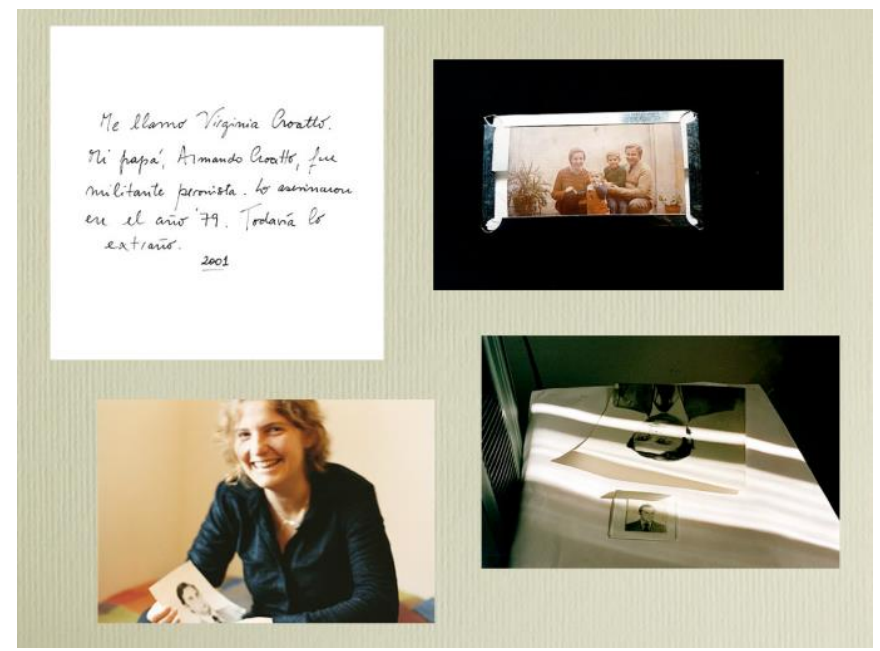


Inés Ulanovsky narra una historia a partir de varias fotos (cuatro, cinco o seis fotos) con un texto manuscrito como punto de partida. Se parte del texto, luego se va hacia atrás, hacia las imágenes de la persona desaparecida, y se llega finalmente a la foto de sus familiares hoy.

\section{Gustavo Germano, Ausencias (2007):}
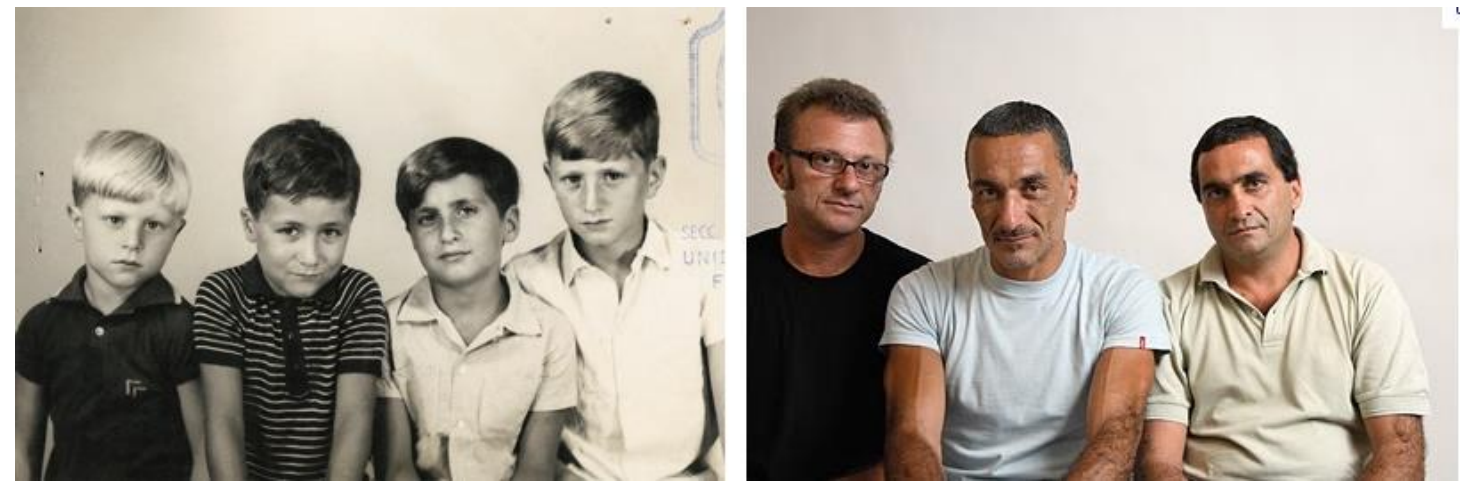

Germano condensa lo esencial de la historia a partir de una serie dípticos fotográficos. El procedimiento de narrar a través de las fotos es similar al de Ulanovsky, pero Germano sólo retiene lo esencial de cada historia -presencia/ausencia- en dos fotos y no incluye textos porque considera que el díptico basta para dar la información que quiere transmitir.

Verónica Maggi, El rescate (2007):

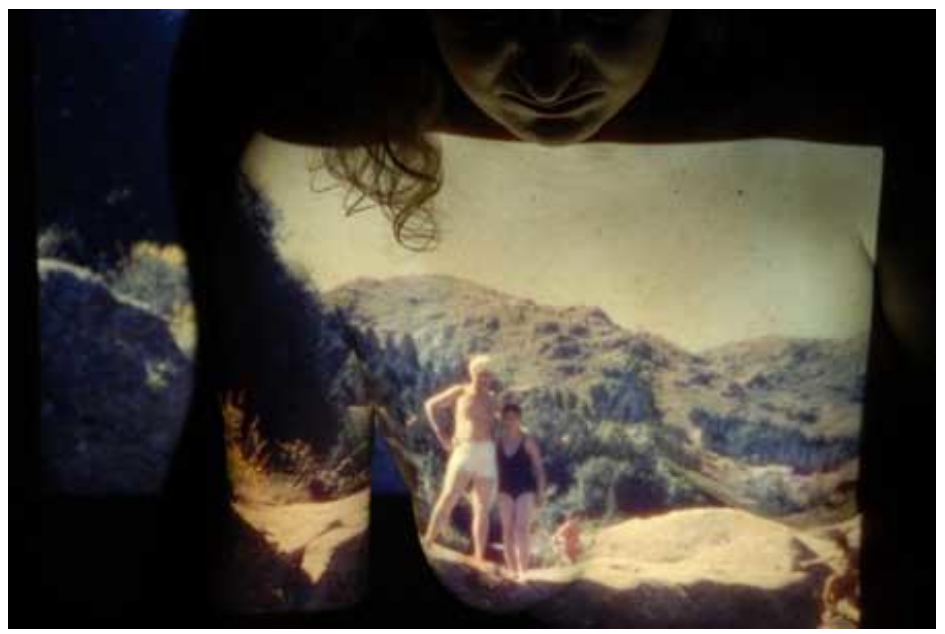

Verónica Maggi utiliza un procedimiento muy cercano al de Quieto, Bettini y Pérez del Cerro, ya que proyecta la foto del pasado sobre su propio cuerpo. Maggi define su propuesta como un cruce entre el pasado que representa su madre para ella y el futuro que representa ella para su madre. 


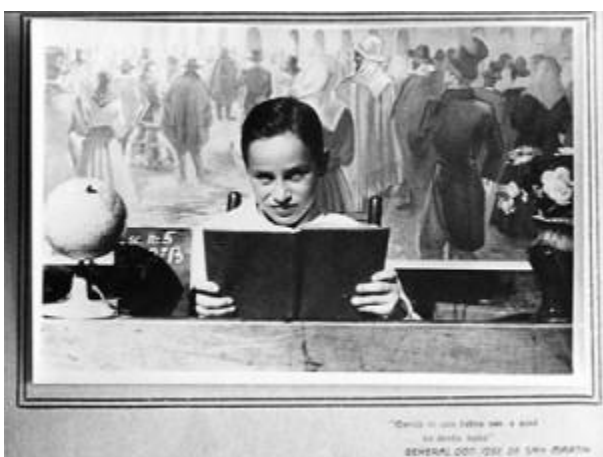

Alberto Jotar, secuestrado octubre de 1977.

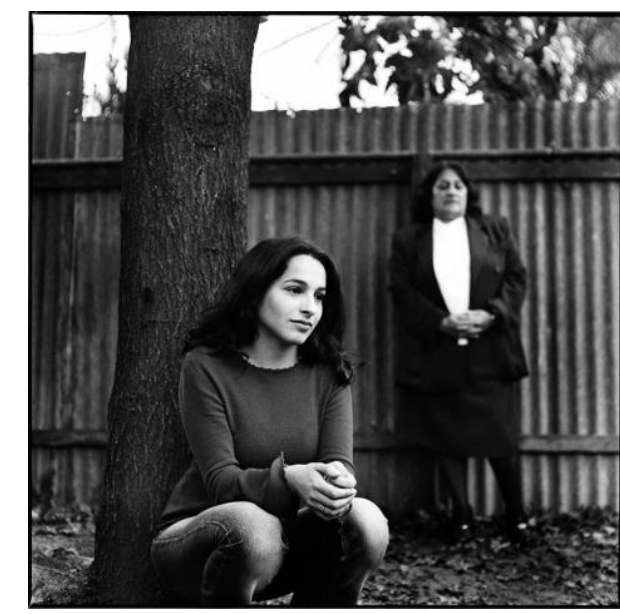

La Plata, Buenos Aires, 9 de agosto de 2001: Laura Jotar (Mara Laura Sfiligoy, secuestrada y recuperada) y su tía Susana Jotar, 48 años.

Martín Acosta fotografía la historia de los nietos a quienes les fue arrebatada su identidad, es decir los hijos de desaparecidos que pudieron reencontrarse con los familiares verdaderos. La muestra construye una serie de encuentros entre el pasado del desaparecido y el presente de sus hijos y parientes, encuentros en los que suele destacarse el parecido entre dos personas ligadas genéticamente, como lo indica el título de la muestra.

Claudia Fontes, Reconstrucción del retrato de Pablo Miguez (2009):

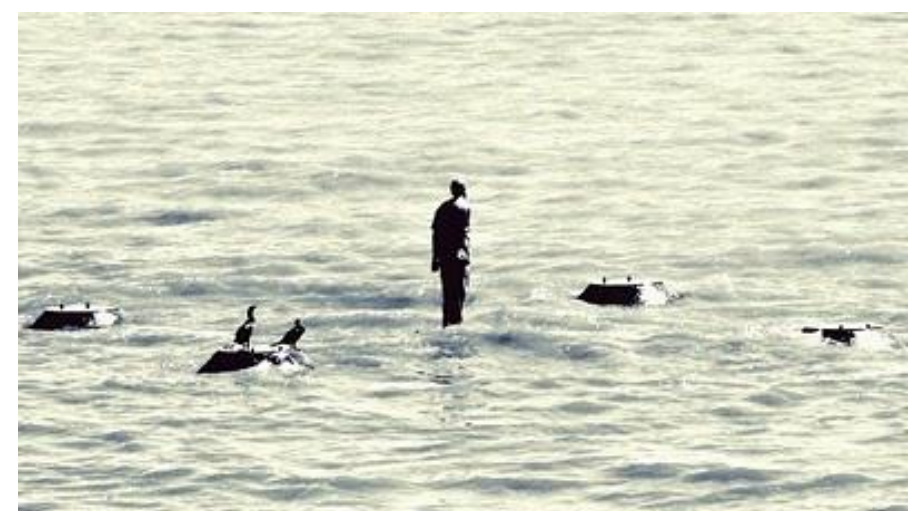

Reconstrucción del retrato de Pablo Míguez

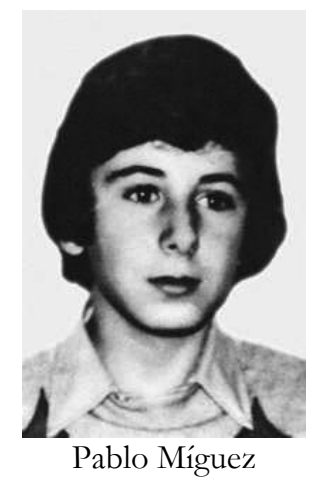


La escultora Claudia Fontes llevó a cabo una reconstrucción muy cuidada del retrato de Pablo Míguez, desaparecido a los catorce años, torturado junto a su madre y eliminado en un «vuelo de la muerte » sobre el Río de la Plata. La imposibilidad de ver el retrato para el visitante del Parque repite la historia de la muerte del adolescente.

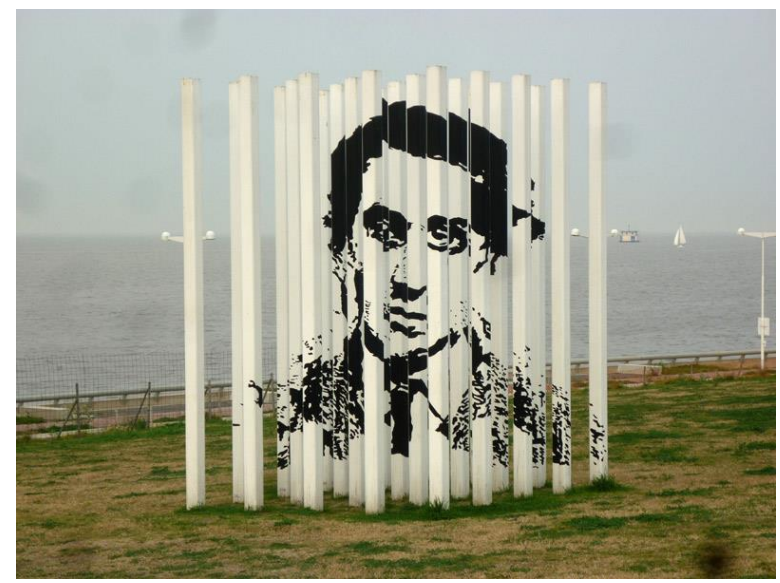

Nicolás Guagnini crea un juego de presencia y ausencia del retrato de su padre, Luis Rodolfo Guagnini, periodista desaparecido en 1977. La foto adquiere un valor paradigmático en la escultura que el artista titula 30000, ya que la escultura propone un recorrido que va del individuo al grupo. Cuando el espectador se desplaza, la imagen aparece y desaparece muchas veces sobre el fondo del río, lugar donde los cuerpos de los desaparecidos fueron arrojados.

\section{Una mirada de conjunto sobre el trabajo de los fotógrafos y artistas plásticos}

En buena parte de los casos que hemos presentado la foto vieja, sacada en el pasado (cuando el desaparecido no era tal ni imaginaba siquiera que alguna vez lo sería), se integra en un dispositivo que le da un nuevo sentido. Ese dispositivo incluye en su mínima expresión dos fotos, una del pasado y una del presente (caso de Germano o Acosta) y, otras veces, un número mayor de fotos (Ulanovsky). Cuando la obra es una escultura, la foto puede en algunos casos verse (Guagnini). En otros casos (Fontes), la foto sirve al artista para reconstruir minuciosamente, en el momento de modelar la estatua, el cuerpo del adolescente desaparecido, pero el visitante del Parque de la Memoria no puede realmente apreciar el trabajo de reconstrucción, ya que la escultura mira hacia el río y sólo se deja ver de espaldas.

En muchos casos los artistas proponen una foto nueva que integra la foto anterior: podríamos decir que hay una suerte de «foto al cuadrado » o un juego de cajas chinas. La integración de lo viejo en lo nuevo se hace:

- de una manera relativamente convencional (un hijo sosteniendo el retrato de su padre, Pantoja)

- o de una manera menos convencional 
$>$ a través del reflejo de los alumnos del Colegio Nacional que miran las fotos del pasado en la muestra de Brodsky,

$>$ o en los juegos llenos de humor propuestos por Bettini,

$>\mathrm{o}$ en las proyecciones de diapositivas que mezclan pasado y presente en las muestras de Quieto y Maggi,

o por el recorte de un detalle y la mirada sesgada en la muestra de Rosson.

Clara Rosson toma un camino original al materializar en la foto las metáforas con las que su subjetividad de hija de desaparecido percibió el pasado: hay pocas fotos del padre desaparecido y hay en cambio fotos movidas o fotos de sombras, que son lo que la figura de su padre y las figuras de los desaparecidos en general significaron durante mucho tiempo para ella ${ }^{10}$.

Helen Zout presenta también un punto de vista particular dentro del conjunto, un punto de vista que es seguramente producto de su experiencia personal y generacional. Es la única dentro del corpus estudiado que intenta registrar la imagen más cercana al momento de la desaparición total y definitiva. Por eso presenta fotos de muertos: un cráneo atravesado por una bala estudiado por el equipo de antropología forense, la foto de la foto de un archivo policial donde se retrata el cadáver de un joven muerto no identificado. Zout -según ella misma dice- se interesa menos en fotos del pasado que en las formas en que ese horrible pasado persiste hoy. Por eso fotografía a muchos sobrevivientes : Nilda Eloy, sobreviviente del centro clandestino Arana de la ciudad de La Plata, mira la cámara con una seriedad hierática que nada parece poder borrar; Víctor Basterra, sobreviviente de la Esma, mira la cámara con una intensidad que confirma el horror vivido y al mismo tiempo afirma la posibilidad de seguir viviendo ; Julio López cierra los ojos como expresando dolor o esfuerzo por recordar cuando Zout lo fotografía, sin saber que, como consecuencia de sus declaraciones en el juicio a Miguel Etchecolatz (mano derecha del jefe de la policía de la provincia de Buenos Aires durante la dictadura), pronto va a convertirse de nuevo en un desaparecido. Las imágenes de varias mujeres sobrevivientes, alguna de ellas sacada en el lugar en que funcionó el centro clandestino de su detención, están movidas o sobre expuestas, lo cual constituye una manera de subrayar el paso del tiempo. Sobre esas fotos dijo Zout en el momento de exponerlas: «Es que el tiempo tenía que fluir dentro de ellas $»^{11}$. Zout no superpone una foto del pasado y una del presente, pero consigue superponer pasado y presente en una misma foto. La muestra incluye fotos de los hijos de los desaparecidos y muchas están tratadas de la misma manera, con una exposición lenta o sobre expuesta, cuyo resultado es una foto movida o poco nítida $^{12}$. En relación con esto, es interesante citar una reflexión de Jordana Blejmar sobre la historia de las fotos de los desaparecidos a lo largo del tiempo:

\footnotetext{
${ }^{10}$ Esto corresponde a una característica a la que se refiere Arfuch en el artículo ya citado para hablar del arte contemporáneo como relato de una « historia posmoderna, alejada de la idea de representación, que no se cuenta por hitos cronológicos, datos precisos, recuerdos nítidos, que no se desenvuelve en una dirección sino que se deja atisbar, imperfecta, a través de fragmentos, colecciones, rastros, inventarios: justamente en la tensión perpetúa entre el vacío de la memoria y el archivo » (ARFUCH, op. cit., p. 37).

11 "Huellas de desapariciones", en Diario Hoy, La Plata, miércoles 29 de marzo de 2006, http://pdf.diariohoy.net/2006/03/29/pdf/19-c.pdf

${ }^{12} \mathrm{La}$ muestra de Zout incluye también fotos de los aviones utilizados en los vuelos de la muerte, fotos del río (tumba de desaparecidos) y fotos de búsqueda de restos fósiles, complemento del acercamiento múltiple de Zout, acercamiento a los desaparecidos, a los sobrevivientes, a los familiares, y a todo tipo de huellas del pasado de las desapariciones en el presente.
} 
Si entonces [en los 80 y 90] las fotos de los desaparecidos se definían por su transparencia y por la sencillez de los retratos, componen estos trabajos imágenes sofisticadas, artificiales, plagadas de referencias, sujetos escindidos, juegos de espejos y refracciones, puestas en abismo, desdoblamientos varios. [...] Ante estas imágenes quebradas no podemos sino experimentar una distancia irrecuperable entre esos rostros y nuestro tiempo (BLEJMAR, p. 204).

\section{A modo de conclusión:}

El elemento común a todos los ensayos fotográficos es el testimonio y la denuncia, tal vez más fuerte en los ensayos fotográficos que tienen un lenguaje más directo (Brodsky, Pantoja, Ulanovsky, Germano), pero presente también en los que usan un lenguaje más complejo y alusivo.

Otro elemento muy presente es el deseo de materializar un encuentro con la persona desaparecida (Brodsky, Pantoja, Ulanovsky, Quieto, Bettini, Maggi, Acosta), como si la nueva foto pudiera, sino borrar, al menos hacer olvidar por un momento la brecha. En muchos de estos encuentros hay sonrisas, alegría, humor, en una clara afirmación de la voluntad de ir más allá del mero dolor y de superar el trauma de la pérdida.

Muchos artistas manifiestan su voluntad de suscitar la participación activa del receptor, incitándolo a reflexionar ${ }^{13}$. Los materiales, la estructura de las obras, el emplazamiento (muy importante en el caso de las esculturas del Parque de la Memoria) dicen tanto como su temática. La desaparición está materializada en las esculturas de Guagnini (por su estructura: el rostro de Rodolfo Guagnini aparece y desaparece) y de Fontes (por su colocación en el río y de espaldas al visitante, que no puede ver el retrato del chico desaparecido). Las fotos metafóricas de Rossón (en las que sólo se perciben sombras), las de Helen Zout que muestran el lento paso del tiempo, las de Quieto o Maggi (que exigen que se las mire con mucha atención para decodificarlas), pero en alguna medida todas las fotos que hemos analizado exigen la participación del receptor para poder ir más allá de la mera denuncia, para poder superar la simple afirmación de que en Argentina bubo (hay) desparecidos ${ }^{14}$. No sólo es cuestión de « recordar»- dice Leonor Arfuch- " ejercitando una facultad de la mente y la afectividad, sino más bien indagar, multiplicar las preguntas, aceptar la tensión irresuelta - quizá para siempre un diferendo » (ARFUCH, p. 37). Sobre este trabajo de interrogación escribió Nelly Richard, en un artículo ya clásico sobre el tema publicado en 2000:

Frente a la neoestetización banal de lo real [...] debemos rearticular políticamente la mirada para que la relación con las imágenes sea intensiva y problematizadora a la vez, es decir, atenta a

\footnotetext{
13 Florencia Battiti habla de «la estrategia estético-conceptual [...] para que el espectador ejerza una experiencia estética activa » que le permita percibir « la carga simbólica de la condición de presencia-ausencia del desaparecido », BATTITI, Florencia, «El arte ante las paradojas de la representación », en Catálogo del Parque de la Memoria, op. cit., p. 79.

14 Sobre la muestra Ausencias de Germano escribe Sebastián Russo: «Siempre hay un resto, algo que sobrepasa lo pensable, lo representable. La evidencia de ese desacuerdo fundador, es lo que le permite a esta obra convocar a una acción (evocadora, restituidora) que conjure, e intente redimir ese horror que sintomáticamente fluye en relación con esos que ya no están, a ese gesto que no se puede reconstruir, a esa falta, ese vacío que excede lo individual, lo familiar, convocando a un necesario re-entramar experiencias, historias, Historia ».
} 
los dobleces (pliegues y sombras: torceduras) de un campo de visión que no puede agotarse en lo mostrable y que debe, al mismo tiempo, frenar esa pulsión de ver que busca consumir todo lo diverso en el espectáculo de la diversión. Habría que desuniformar la percepción para reafectivizar el recuerdo: producir rupturas de tono o quiebres de expresión para disociar la lógica de imperturbabilidad de la serie que produce la anestesia: restituirle al recuerdo toda su fuerza crítica de subjetividad y experiencia, de dislocación significante, mediante nuevas conexiones intensivas entre texturas, marcas y acontecimientos. (RICHARD, p. 33)

Terminaremos esta reflexión con una cita de lo que Florencia Battiti escribe en el Catálogo del Parque de la Memoria:

Pareciera entonces que, ante el límite, el arte sufre una suerte de insuficiencia de representación pero, paradójicamente, logra fundarse en esa misma imposibilidad. Lo que ocurre es que a partir de las experiencias concentracionarias del Holocausto el arte en tanto producto de la "civilización" sufrió una estocada y fue cuestionado en su capacidad para referir lo ocurrido. Sin embargo, y a pesar del evidente corte civilizatorio que implica para el caso argentino el fenómeno de los desaparecidos, el arte no ha cesado en su intento por interpelar estas experiencias participando activamente en el proceso de construcción de las memorias que la sociedad argentina emprendió a partir de la recuperación de la democracia.

Los artistas contemporáneos asumen el desafío de documentar y procesar el horror, contribuyendo a la construcción de la memoria, posibilitando un diálogo entre personas y tiempos diversos y creando un espacio donde los límites entre lo privado y lo público pierden relevancia y donde tanto las imágenes de los desaparecidos como los dispositivos de montaje en que ellas se insertan incitan a la reflexión. Esta reflexión parece indispensable para que la historia no pueda repetirse.

Bibliografía: Todos los sitios web citados eran accesibles en el mes de noviembre de 2011.

Corpus fotográfico utilizado por los militantes de derechos humanos y por las familias de los detenidos y desaparecidos

Fotos en manifestaciones de derechos humanos, en edificios donde hubo centros de detención y tortura y en páginas web: http://www.reportealdia.com.ar/?p=3374 (foto de una manifestación)

http://www.elpais.com/articulo/internacional/ultima/imagen/desaparecidos/elpepuint/20051120 elpepiint_7/Tes (fotos en las rejas de la Escuela de Mecánca de la Armada)

http://www.desaparecidos.org/arg/victimas/muro2.html (muro de la memoria: fotos de una parte de los desaparecidos)

http://defensadelconsumidor.buenosaires.gov.ar/institutomemoria/media/fotos/fotos.html http://www.desaparecidos.org/arg/victimas/muro2.html

Fotos como prueba en juicios (ej. fotos sacadas por Basterra de la ESMA): http://www.desaparecidos.org/nuncamas/web/investig/basterra/basterra_01.htm 
http://defensadelconsumidor.buenosaires.gov.ar/institutomemoria/notas/071121muestra2.html (fotos de detenidos y desaparecidos y de represores)

BASTERRA, Víctor, Rostros (2007):

http://defensadelconsumidor.buenosaires.gov.ar/institutomemoria/notas/071121 muestra2.html http://www.taringa.net/posts/info/3294456/las-fotos-de-Basterra-_-rostros-del-horror.html

BRODSKY, Marcelo (compilador), «Sacar fotos ", en su Memoria en construcción. El debate sobre la ESMA, Buenos Aires, La Marca Editora, 2005.

Fotos como argumento sobre la identidad.

Sobre la posible identidad Marcela Noble y Matilde Lanuscou:

GOOBAR, Walter, «Marcela Noble y la historia de Matilde», 4 de diciembre de 2010, Buenos Aires, Tiempo Argentino. Puede consultarse en:

http://tiempo.elargentino.com/notas/marcela-noble-y-historia-de-matilde

Sobre la posible identidad de Matilde y Clara Anahí Mariani:

http://www.taringa.net/posts/offtopic/8563448/Marcela-Noble-Herrera--es-en-realidad-ClaraAnahi-Mariani.html

Siluetas.

Fotos en el libro de BRUZZONE y LONGONI, El siluetaæo. Libro consultable en: http://www.slideshare.net/alejafonse/el-siluetazo

Escultura de Roberto AIZENBERG en el Parque de la Memoria: http://www.panoramio.com/photo/75098888

Fotos de recordatorios de Página 12:

http://homenajesdesaparecidos.blogspot.com/2008/07/recordatorios-pgina-12.html http://www.pagina12.com.ar/diario/elpais/1-110291-2008-08-24.html (a los veinte años de la publicación del primer recordatorio).

Muestras fotográficas (en orden cronológico)

BRODSKY, Marcelo, Buena memoria (1997) y Nexo (2001)

http://www.marcelobrodsky.com/ de 1997)

BRODSKY, Marcelo, Buena memoria, Buenos Aires, La Marca editora, 2006 (primera edición

PANTOJA, Julio, Los hijos, Tucumán veinte años después (1996-2001)

http://www.me.gov.ar/a30delgolpe/fotogaleria/julio_pantoja/

QUIETO, Lucila, Arqueología de la ausencia (1999-2001)

http://www.me.gov.ar/a30delgolpe/fotogaleria/hijos_fotos_y_legados/

http://www.slideshare.net/lalunaesmilugar/arqueologia-de-la-ausencia

BETTINI, Gabriela, Recuerdos inventados (2003)

http://picasaweb.google.com/gabriela.bettini/RecuerdosInventados?authkey=CoUUdenc5tE\#slid eshow/5258573201270836194 
ZOUT, Helen, Huellas de desapariciones (2003). Hay otras muestras. http://www.helenzout.com.ar/

PÉREZ DEL CERRO, Pedro Camilo, El viaje de papá (2005) http://argentina.indymedia.org/news/2005/12/354887.php

ROSSÓN, Clara, Tarde (o temprano) (2006)

http://www.me.gov.ar/a30delgolpe/fotogaleria/hijos_fotos_y_legados/

ULANOVSKY, Inés, Fotos tuyas (2006)

http://www.me.gov.ar/a30delgolpe/fotogaleria/ines_ulanovsky/

http://www.taringa.net/posts/arte/9791940/Arte-y-Memoria---Fotos-Tuyas---Ines-

Ulanovsky.html

GERMANO, Gustavo, Ausencias (2007)

http://www.gustavogermano.com/

http://www.youtube.com/watch?v=Cr-6byhIVZw

http://www.slideshare.net/fuenteovejuna/gustavo-germano-proyecto-ausencias

http://www.vgroupnetwork.com/foro/43140-fotografias-de-gustavo-germano-ausencias.html

MAGGI, Verónica, El rescate (2007)

http://www.veronicamaggi.net/gallery/folio.html

http://itinerariofotografico.wordpress.com/veronica-maggi/

ACOSTA, Martín, ADN (2001-2007)

http://revistanuestramirada.org/galerias/martinacosta

http://pablosincalma.blogspot.com/2008/10/muestra-de-fotos-adn-de-martn-acosta.html

FONTES, Claudia, Reconstrucción del retrato de Pablo Míguez (2009)

http:/ / factorfotos.blogspot.com/2011/02/claudia-fontes-reconstruccion-del.html

GUAGNIGI, Nicolás, 30000 (2008). Escultura que reutiliza una foto del padre del artista. http://juanelear.com/resenas/heridas-en-direccion-al-rio-el-parque-de-la-memoria/?lang=es

Estudios sobre el tema:

ALEGRE, Gabriela y AYERDI, Cecilia, «La aparición de los nombres. Un monumento en permanente construcción » en Catálogo del Parque de la Memoria, Buenos Aires, Consejo de Gestión del parque de la Memoria, 2010, p. 56-65.

ARFUCH, Leonor «Arte, memoria y archivo », in Punto de vista $\mathrm{N}^{\circ}$ 68, diciembre, 2000, p. 34-37.

BATTITI, Florencia, «El arte ante las paradojas de la representación », in Catálogo del Parque de la Memoria, op. cit., p. 71-88. 
BLEJMAR, Jordana, "Anacronismos », in El río sin orillas. Revista de Filosofía, Cultura y Política, No 2, Buenos Aires, X/2008, p. 200-211.

BROSKY, Marcelo (compilador), Memoria en construcción. El debate sobre la ESMA, Buenos Aires, La Marca Editora, 2005.

BRUZZONE, Gustavo y LONGONI, Ana (compiladores), El siluetazo, Buenos Aires: Adriana Hidalgo Editora, 2008.

DURÁN, Valeria, «Fotografías y desaparecidos: ausencias presentes », Cuadernos de Antropología Social No 24 (revista del Instituto de Ciencias Antropológicas. Sección de Antropología Social de la Facultad de Filosofía y Letras de la Universidad de Buenos Aires), p. 131-144, Buenos Aires, 2006. Puede consultarse en:

http://redalyc.uaemex.mx/redalyc/pdf/1809/180914244006.pdf

KUSCHNIR, Silvia, «Corporalidad y memoria en ensayos fotográficos sobre la experiencia del campo de concentración en la Argentina », 2009, in

http://www.slideshare.net/Silvia_m_k/corporalidad-y-memoria-en-ensayos-fotogrficos

KUSCHNIR, Silvia, «Hablando desde los escombros: (des)ocultamiento del cuerpo en fotografías sobre los Centros Clandestinos de Detención en Argentina ", ponencia presentada en el III Seminario Internacional Políticas de la Memoria. Recordando a Walter Benjamin: Justicia, Historia y Verdad. Escrituras de la Memoria, Buenos Aires, octubre de 2010. Puede consultarse en:

http://www.scribd.com/doc/46440464/Hablando-desde-los-escombros http://www.slideshare.net/Silvia_m_k/hablando-desde-los-escombros-desocultamiento-delcuerpo-en-fotografas

FELD, Claudia, «Imagen, memoria y desaparición. Una reflexión sobre los diversos soportes audiovisuales de la memoria ", Buenos Aires, in Aletheia (Revista de la Maestría de Historia y Memoria de la Facultad de Humanidades y Ciencias de la Educación), volumen I, No 1, octubre de 2010, La Plata, Argentina. Puede consultarse en:

http:/ /www.aletheia.fahce.unlp.edu.ar/numeros/numero-1/numeros/numero-1/feld-claudia.imagen-memoria-y-desaparicion.-una-reflexion-sobre-los-diversos-soportes-audiovisuales-de-lamemoria

FORTUNY Natalia, « Memoria fotográfica. Restos de la desaparición, imágenes familiares y huellas del horror en la fotografía argentina posdictatorial », in Amerika (Revista electrónica del Laboratoire Interdisciplinaire de Recherche sur les Amériques de la Universidad de Rennes 2, inscrita en la plataforma francesa revues.org), Año 1, $\mathrm{N}^{\circ}$ 2, 2010. Puede consultarse en: http://amerika.revues.org/1108

FORTUNY, Natalia, «Palabras fotográficas: imagen, escritura y memoria en dos series de Marcelo Brodsky », in Papeles de Trabajo (Revista electrónica del Instituto de Altos Estudios Sociales de la Universidad Nacional de General San Martín), Año 4, N 7, abril de 2011, p. 31-43. Puede consultarse en:

http://www.idaes.edu.ar/papelesdetrabajo/paginas/Documentos/03)\%20Palabras\%20fotográficas

\%20imagen, $\% 20$ escritura $\% 20 \mathrm{y} \% 20$ memoria $\% 20$ en $\% 20$ dos $\% 20$ series $\% 20$ de $\% 20$ Marcelo $\% 20$ Brods ky.pdf 
GATTI, Gabriel, «Las narrativas del detenido-desaparecido (o de los problemas de la representación ante las catástrofes sociales)», CONfines 2/4 (Publicación semestral del Departamento de Relaciones Internacionales y Ciencia Política de la División de Humanidades y Ciencias Sociales del Tecnológico de Monterrey), Monterrey, México, agosto-diciembre de 2006, p. 27-38. Puede consultarse en:

http://confines.mty.itesm.mx/articulos4/GGatti.pdf

GUSMÁN, Luis, Epitafios. El derecho a la muerte escrita, Buenos Aires, Grupo Editorial Norma, 2005, « Postfacio: El derecho a la muerte escrita », p. 325-356.

LONGONI, Ana, «Fotos y siluetas: políticas visuales en el movimiento de derechos humanos en Argentina », in Afterall Journal No25 (Revista de arte contemporáneo coeditada por la Universidad Internacional de Andalucía), otoño/invierno 2010. Puede consultarse en:

http://ayp.unia.es/dmdocuments/afterall_25_\%20analong.pdf

LONGONI, Ana, «Arte y Política. Políticas visuales del movimiento de derechos humanos desde la última dictadura: fotos, siluetas y escraches ", in Aletheia (Revista de la Maestría de Historia y Memoria de la Facultad de Humanidades y Ciencias de la Educación), volumen I, No 1, octubre de 2010, La Plata, Argentina. Puede consultarse en:

http://www.aletheia.fahce.unlp.edu.ar/numeros/numero-1/pdfs/Longoni-

$\% 20$ Aletheia $\% 20 \mathrm{vol} \% 201 . \% 20 \mathrm{n} 1 . \mathrm{pdf}$

LONGONI, Ana, "El siluetazo y su legado», en Territorio teatral $\mathrm{N}^{\circ} 2$ (revista digital, publicación semestral del Departamento de Artes Dramáticas, Instituto Universitario Nacional del Arte), Buenos Aires, diciembre de 2007. Puede consultarse en:

http://territorioteatral.org.ar/html.2/articulos/pdf/n2_01.pdf

RICHARD, Nelly, «Memoria, fotografía y desaparición: dramas y tramas », in Punto de vista $\mathrm{N}^{\circ}$ 68, diciembre, 2000, p. 29-33.

RUSSO, Sebastián, «(In)armonías, imágenes y memoria. Sobre la muestra fotográfica Ausencias de Gustavo Germano ", Questión (Revista Especializada en Periodismo y Comunicación de la Facultad de Periodismo y Comunicación Social de la Universidad Nacional de La Plata, Argentina), Vol 1, No 20, 2008. Puede consultarse en:

http://www.perio.unlp.edu.ar/ojs/index.php/question/article/view/706/609

STRELEZENIA, Marisa, "Fotografía y memoria : la escena ausente " (sobre Arqueología de la ausencia de Lucila Quieto), ponencia presentada en las II jornadas de Fotografía y sociedad, Facultad de Ciencias Sociales de la Universidad de Buenos Aires, septiembre de 2001, publicada en Ojos crueles, temas de fotografía y sociedad $\mathrm{N}^{\mathrm{o}} 1$, Buenos Aires, octubre de 2004-marzo de 2005. Puede consultarse en:

http://www.studium.iar.unicamp.br/20/ausencia/Strelczenia.pdf 